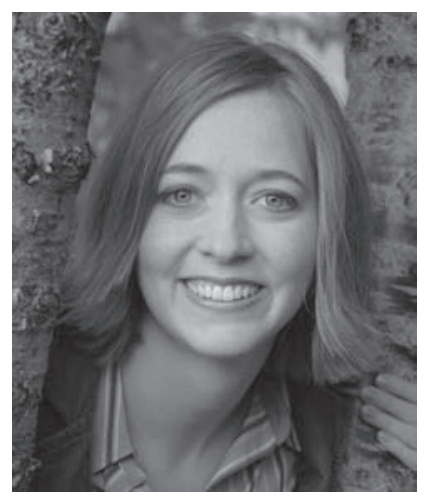

\title{
"Our World with One Step to the Side": YALSA Teen's Top Ten Author Shannon Hale Talks about Her Fiction
}

TAR: This quotation in the Salt Lake City Deseret News would probably be of interest to inspiring creative writing majors: "Hale found the creative-writing program at Montana to be very structured. 'You get in a room with 15 people and they come at you with razors. I became really tired of the deathoriented, drug-related, hopeless, minimalist, existential terror stories people were writing.'” This seems to be the fashion in university creative writing programs, but it is contrary to the philosophy of secondary English ed methods of teaching composition classes (building a community of writers where the environment is trusting and risk-taking is encouraged as opposed to looking for a weakness and attempting to draw blood). What do you find is the best or most useful approach to responding or seeking response to your work in its early drafts?

Shannon: I don't know that the University of Montana supported any particular philosophy. It was more determined by the attitudes of the instructor and the participants. I think what made $\mathrm{U}$ of $\mathrm{M}$ different than, say, my undergrad workshops, was that everyone there was very serious about becoming a writer. This was not a fun elective class-this represented a serious gamble of time, money, and hope, and no one took it lightly. I don't think anyone set out to be harsh, but we were. In a way, I think that's good because it helped me to develop a tough skin, which any artist needs to have to face the rejections (I had dozens of rejections before I ever received my first acceptance) and reviews and slow sales ...

Regardless of the type of environment, I think the workshopping experience is helpful because I learned to accept feedback on my own work, even if ultimately it didn't take me where I want to go (it's all for practice at that point!). As well, reading and giving feedback on early drafts of other people's work was crucial for training me to be a better editor of my own writing.

What I don't like (and I don't think this is a program-specific problem) is the mob mentality that springs from a workshop-style setting. Anything experimental, anything too different, is going to get questioned or criticized. I found myself changing what I wrote, trying to find what I thought would please my professors and colleagues, not trying to find what most pleased me. This is one reason why, I think, publishable material is rarely produced in an MFA program. I wrote The Goose Girl after graduating.

TAR: How do you see the role of a female protagonist or how do you want your female protagonist to be perceived by your readers?

Shannon: I'm very lucky to be writing after decades of writers have fought for their genuine, interesting, and varied heroines. I don't have the burden of writing on offense, trying to prove that girls actually are interesting enough to be main characters and do come in various shapes and kinds. It's a luxury I'm mindful of often. I now get to go forward and tell stories as though it's always been this way. I get to think of myself as a realist instead of as an aggressive feminist. 
As a storyteller, I was drawn to powerful girls who lacked masculine strength and interesting girls who didn't swing a sword. Although I think it's fabulous that "girls with swords" stories exist (at last!), I consciously chose to tell another side of that-girls don't have to fall into traditionally male roles in order to be powerful or interesting. I'm not athletic, I'm not physically strong (and am very aware of it next to my 6'3", 300-pound-bench-pressing husband), and I want to shout out to all my sisters out there that we're just as good as the marathon runners. I still stumble across the idea that the "cool" girls, the honorable girls, are the ones that grew up wrestling in the dirt and eating worms and never crying. Why? I don't want to propagate that nonsense.

TAR: While you were writing Princess Academy you held down a full-time job, taught Sunday school, cared for a husband and looked after a son, and those are just the things we know about!! Many people will say, "I am leaving my job to raise a family" or "I am leaving my job to write a book" or "when my kids are grown, I will have time to pick my writing career up again," but not you. How do you do it and what is your philosophy around all of that?

Shannon: I know lots of women who want to be writers but can't or don't get started until after the kids are in school. I feel very lucky to have had a head start. A big part of it for me was the MFA. Contrary to what I had supposed, the MFA program did not hook me up with contacts in the publishing world, teach me the secrets of storytelling, or help me produce the great American novel-but it did help me to fall into the habit of writing every day. That was invaluable.

I had started The Goose Girl before I was married and sent off the final draft of Enna Burning a week before the birth of my first child. (I just have the one, or indeed this would be nearly impossible.) Now the mania is firmly in control, and I MUST write. I've always thought that the drive to write was a form of mental illness, and in many ways it's helpful. When you have to do something, like going to the bathroom, you'll find a way. I certainly can't write as much as I used to (the period when I worked full time and had a baby was very difficult), but I'm home now with Max. I wrote the first draft of Princess Academy during maternity leave with him asleep or playing on my lap. I did the rewrites in the evenings and, when I got to quit my job, during nap times. When we have another baby someday, I imagine my output will greatly slow down, but I don't think I could ever stop now.

TAR: What role do parents and teachers play in developing a young person's love of literature?

Shannon: Huge! I attend an inner-city church and teach 8- to 11-year-old girls on Sundays, and every week I ask them if they've been reading. The ones that do are the ones with parents that read with them and take them to the library. The girls whose parents neglect reading and don't read books themselves, almost never read. My own parents always read to us.

I think teachers and librarians are so important too in pointing kids to books they'll enjoy. In my experience, kids who don't like reading (barring developmental issues and learning disabilities) just haven't found the kinds of books that capture their interest. I remember re-reading the same books over and over because, in part, I didn't know where to go to find something else I liked. I didn't even realize there might be more books out there for me. What a tremendous gift it would be to give kids monthly one-on-one time with a librarian or reading specialist who could talk to them, figure out their interests, and place them with a handselected book. 
TAR: What role does fiction reading play in a person's life, young, old or in between?

\section{Shannon: I've spoken to teacher} groups before who are passionate about getting kids to read, and then I ask, "How many of you have read a book for pleasure this past month?" The response is appallingly low. Adults start to get so stubbornly practical, we think we need to be constantly productive, reading non-fiction and self help and such, and believe that fiction is frivolous and a waste of time. Didn't we do away with this notion already? No room in the Republic for poets? Yikes! I wish I knew irrefutable scientific evidence to prove it, but I just believe that our brains need great fiction books. For me as a kid, reading was escape, adventure, relief, entertainment, confidence building, instructional, character forming. . . . While those needs are more intense in children, they certainly don't go away. Adults need fiction, too!

TAR: Does your use of fairy tales reflect any sort of beliefs in archetypes or stories common to the human experience across time and cultures?

Shannon: Absolutely. I chose to write a novel from "The Goose-Girl" because it had always been my favorite fairy tale, and I thought, if this is a story that survived decades and perhaps centuries in oral form, there must be some universal truth here. Little children will ask for the same book read to them again and again, night after night, because it satisfies something in them, soothes some need in their current development. Fairy tales are the stories we tell ourselves again and again. I love that we as readers have the same need for stories that people did hundreds of years ago. I love that "Cinderella" has reappeared in dozens of forms in dozens of countries over the past 1500 years. It was around my eighth draft of Princess Academy that I suddenly realized, hey, this could be read as a retelling of Cinderella!
TAR: What is left out of a fairy tale as told by the Brothers Grimm? Why were their tales so violent? How do you decide what to keep and what to leave out, especially in regard to the violence?

Shannon: The Grimm brothers did a service in recording those oral tales, but they also permanently froze their version of the tales. How was "The Goose-Girl" different when a grandmother told it by a fire in Austria? What happened to Little Red Riding Hood according to some hausfrau 300 years ago? There's no way we can know what was lost-which is why I love that so many writers retell the tales. That's what they're for! No one's version is the right one.

Violence is tricky, because it's "bad." I as a

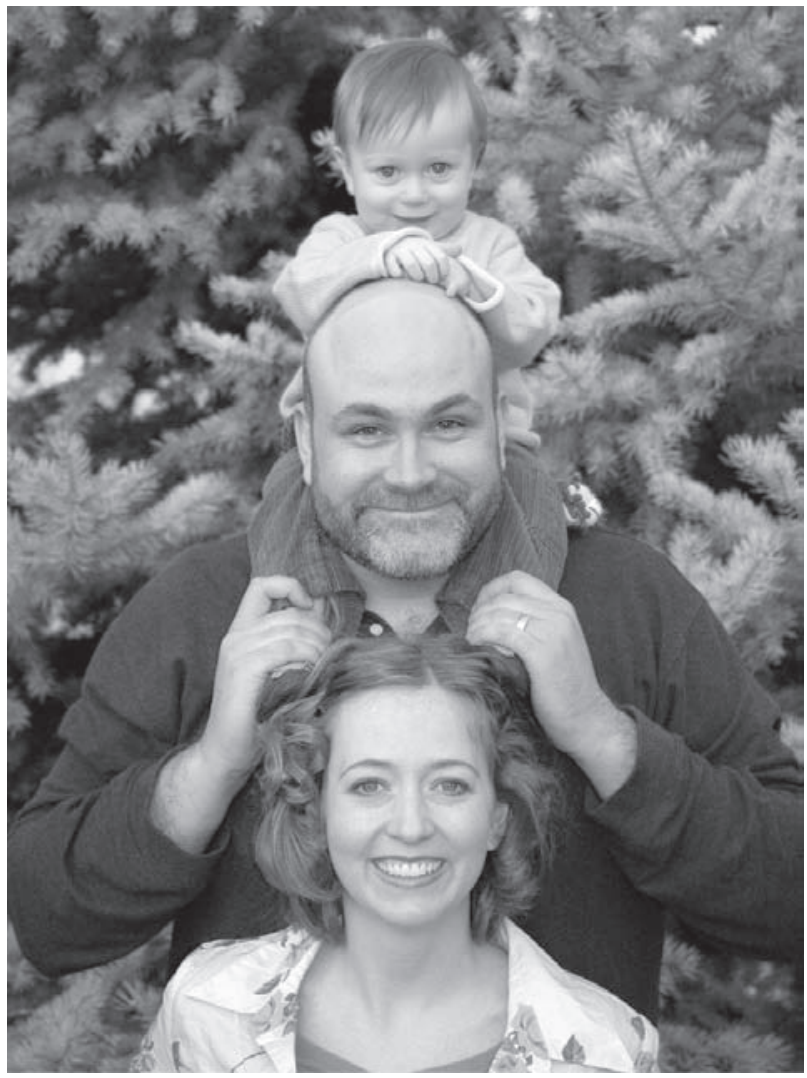


reader don't like to read gratuitous violence, but I did feel it was important to pay homage to the elements of the original tale. I decided, for instance, to keep the lady-in-waiting's horrid fate but let it happen offstage. As well, I didn't want to see the horse die, though that event is essential in the princess's development. Fairy tales are where we experiment with the bad bits of life in a safe environment, and where we find out that there is always hope and always the possibility of a happy ending. To completely Disney-fy them defeats the wholeness and brilliance of these tales.

TAR: Is there a purity or honesty about animals compared to the dishonesty and deceitful nature of people? Why do animals so often play a role in fairy tales in which the protagonists are people?

Shannon: I think animals are highly symbolic. You can say, "fox," "horse," "lion," "vulture," and immediately get a sense of character type. They certainly represent different aspects of personality and characteristics inside every human. I think it's also a study of agency, which is a major component of fairy tales. People make choices while animals respond to instinct.

TAR: Ani was headed for an arranged marriage to someone she has never even met and meets with an obstacle of gigantic proportions. You knew your husband for 12 years before marrying him. Anything going on under the surface here?

Shannon: Ha. Yes, I suppose there might be, though not consciously. While writing, I tried to do justice to the original tale, keep what was essential to it, and make it interesting and believable. But my own life experiences must play a role in how I interpret what the story is and how to tell it! Certainly I do believe in life companionship, romantic love, and happy endings after long struggles.

TAR: You may have been asked this so many times you hate to hear it again, BUT, does Ani fit Joseph Campbell's Hero's Journey, and if so, was this a conscious construction or just another evidence of the universality of stories, heroes and the human experience?
Shannon: No conscious construction, though I am familiar with the theory. I think Campbell's brilliance is he saw the pattern laced inside the world's stories.

TAR: (OK, this may sound silly, but) Does Enna Burning have anything in common with the X-men series? People with special powers who must face many challenges above and beyond what nonmutants face, including learning to wield powers and learning to cope with being different?

Shannon: That's an interesting connection. I hadn't thought of it. I do love superheroes, comics, and I do know the X-men series, so perhaps on an unconscious level it slipped in. The type of "magic" I developed to tell The Goose Girl came about from what I found in the original tale-there was a talking horse, a close connection to geese, and a mystical power over the wind, and from there I created a magic system that would work for me. I had decided not to create a world where people with superpowers run rampant or magic abounds. I wanted it to feel real and possible, our world with one step to the side, and not alienate non-fantasy readers. So the stories do deal with people who have abilities that are not common.

TAR: What went through your mind when you were announced as being in YALSA Teens' Top Ten for The Goose Girl?

Shannon: Surprise, delight, relief, elation...some mix of all that, I think. The Goose Girl hadn't been included on any ALA lists, so it was especially nice. I love that the teen readers themselves get to bestow an honor. Some of those authors on the list like Rowling and Cabot already have so many honors and best seller status and on and on that it can't be a big deal for them anymore, but for little people like me, these things are huge! My publisher forwarded me the announcement in email, and I was thinking, "Dang! Shouldn't there be a parade or something?" I doubt such awards and honors mean as much to anyone as to the novice novelist. 


\section{The Goose Girl}

Reviewed by Jean Boreen, Northern Arizona University, Flagstaff, Arizona

$\mathbf{F}$ ans of retold fairy tales will enjoy Shannon Hale's version of the Grimms' story of the princess who must endure life as a goose girl before she can become queen. Goose Girl introduces us to the Crown Princess Anidori-Kiladra, otherwise known as Ani, who is born with the gift of animal-speak. As a young child, she is aided in her learning by her aunt, who shares the same gift as Ani; however, after Ani's mother becomes suspicious of her daughter's relationship with her aunt, she sends her sister away and puts Ani under rigorous "princess training." As Ani grows older, she comes to understand and somewhat fear her own mother's gift of "people-speak" (the ability to direct other people's actions through her words).

When Ani's father dies, the sixteen-year-old crown princess finds that her mother plans to usurp Ani's right to the throne in favor of her younger brother, Caleb. Questioning her mother, Ani finds that the queen has promised her daughter in marriage to the eldest son of the king of Bayern. Both Ani and the queen know that Bayern has turned its eyes to conquering Kildenree. With no recourse, Ani is sent to Bayern with her lady-inwaiting, Selia, and a small troop of Kildenree soldiers; her only true friend on the trip is her mount, Falada, the horse she has raised since childhood. And Falada is the only one who comes to her aid when Selia, supported by the captain of the guard, Ungolad, determines to kill the princess and take over her identity.

It is here where Ani's journey to adulthood truly begins. Betrayed by those she trusts, she turns to the animals of the forest into which she escapes. She is also befriended by the widow Gilsa and her son when she becomes desperate for food and directions to the Bayern capitol; although Ani has been consistently betrayed by her mother and other Kildenreans, she is determined to continue on to the city to reclaim her rights as princess and wife-to-be of the crown prince. However, getting on to the palace grounds and into the palace itself is not an easy task, and Ani takes a job as the goose keeper to obtain access to the grounds. The job is demanding, but through it, Ani learns a great deal about friendship, loyalty, and love.

With a new cunning born of friendship as well as desperation, Ani uncovers the whole of Selia's evil plans: to encourage Bayern to go to war against Kildenree so that there will be no one to challenge Selia's claims to power. Gathering support from the forest peoplethose who are considered to be second-class citizens in Bayern because they lack the opportunity to earn a javelin, one of the mightiest symbols of power in the war-driven country-and those with whom she has worked in the palace yard, Ani forces the king of
Bayern to listen to her claims. But it also takes the assistance of the young soldier Geric, who is, in truth, the heir to Bayern and Princess Ani's intended, to make the king and his circle understand the true intentions of Kildenree.

Fairy tales were created to provide children with some type of moral compass from which to make decisions. As with most retold fairy tales, The Goose Girl provides adolescent readers with much to consider as far as relevant life themes. In this novel, one of the most obvious is the development of one's identity apart from others' expectations. As Crown Princess, Ani has had her life defined by others' expectations of what a princess is. More importantly, and probably more painfully, Ani has been impacted by her mother's disapproval of her ability to animalspeak. Ani also senses that people see her as clumsy, both physically and verbally. Her ability to work with the horses she and her father love is dismissed as unladylike. It is not until Ani is forced to fend for herself that she begins the necessary process of self-evaluation. While becoming a goose girl is difficult, it is the manner in which Ani handles the job and those with whom she works in the palace stables/yard that gives her the confidence to begin asserting herself in those relationships and in her relationship with Geric. These relationships are also influenced by Ani's ability to animal-speak, the 
talent she can actually develop once she is away from the punitive attitudes of her mother and Selia. Ani's confidence in working with Falada, the geese, and Geric's seemingly irascible horse grows to the point that she is able to shift that self-assurance to her interactions with humans. This newly mastered poise enhances the leadership skills Ani had never been allowed to develop under her mother's control. By the end of the novel, Ani is confident enough to demand her rightful place as Crown Princess of Kildenree and to express her love for Geric.

Ani's growth and eventual selfidentification is an important evolution for younger readers to consider. All of us struggle with identity; our contemporary society sends mixed messages to young people all of the time, whether through the advertisements on television or in magazines, the popups that blanket their computer screens, or in the lyrics to the music they sing. Reality shows like "The Bachelor" and MTV's "Real Life" present a way of life that seems very less than real to many of us, yet they, too, influence how young people think about themselves and others, and often lead to a kind of ruthlessness in how we view people who aren't "perfect." For those reasons alone, it is imperative that younger readers have access to texts that encourage them to consider how other people/characters define themselves within social and societal situations.
Another important conflict in this novel focuses on issues of loyalty and power. Throughout the novel, various characters-the Queen, Ani, the King of Bayern, Selia-argue that they make their decisions based on the good of their countries. However, only Ani actually seems concerned with the good of the people of her sovereign state, quite opposite of the machinations of the Queen, the King of Bayern, and Selia. In their various cases, the good of the country is used as an excuse to bolster personal positions. The Queen of Kildenree retains her power after her husband's death by moving Ani out of the picture of favor of her more malleable younger brother. The King of Bayern rules a country with very specific ideas about military prowess and its impact on the class system within the country; to consolidate his power, he provides various opportunities to his upper caste to war on others and reap the benefits. Selia, the daughter of the Queen of Kildenree's key mistress (a formidable personage in her own right), has been raised to think herself as good as the Crown Princess; Selia finds that easy since she is more at ease with those in power than Ani seems to be. Indeed, Selia also has the same gift of "people-speak" Ani'a mother has, although she has not honed it to the level of the Queen. Selia's usurpation of Ani and her portrayal of the Crown Princess to the Bayern people solidifies Selia's grasp for power; her further willingness to trick
Bayern into a war on Kildenree is key to consolidating her position and making sure that no one can question who she is within Bayern.

While younger readers may not be as interested in the political intrigues Ani uncovers, they should be interested in Ani's developing appreciation of what true friendship and loyalty really look like. When Ani is forced to become the goose girl, she learns that she cannot take everyone at face value; rather, she must get to know people as individuals. In her interactions with the Bayern forest people-those who are not considered the highest class-Ani learns that they embody the goodness, loyalty, and friendship she thought she would never find. In her friend, Enna, Ani finds someone to whom she can turn to and confide her feelings about Geric, her fear of losing her name forever, and her concerns about the war against Kildenree. With Enna's aid, Ani is able to rally the forest people to her cause and confront the King with the truth about Selia and Kildenree.

The Goose Girl is an excellent story for those readers who enjoy a fantasy firmly grounded in a character who is easy to relate to on a number of levels. Ani's experiences and journey toward self-identity provides a wonderful blend of escapist literature with life truths that make this book a delightful read.

Hale, Shannon. 2003. The Goose Girl. New York: Bloomsbury. 383

pp. ISBN: I-58234-843-X. US \$17.95. 


\section{Enna Burning}

Reviewed by Lori Atkins Goodson

n Enna Burning, Shannon Hale's

sequel to The Goose Girl, Enna, prompted by the illness of her mother, has left the city and returned to the Forest to live. After the death of her mother, Enna and her brother, Leifer, carry on their rather simple lives. But their Forest life shifts drastically when Leifer brings home a mysterious piece of vellum he has found buried beneath the ground. That vellum gives him insight into a new talent-starting fires from a power within him.

Enna first senses the danger when, in a fit of anger, Leifer sets the edge of her dress ablaze during an argument. Aware of her brother's volatile abilities, Enna then watches as Leifer uses his newfound ability to help the King battle an invading army. With the king killed in battle, Leifer helps the King's army push back the invaders by setting the enemy and the battlefield afire. Once again, Enna has seen the power-and the destruction-the language of fire can bring.

With her brother's death on the battlefield in his heroic efforts, Enna takes the undamaged vellum from her brother's charred corpse and begins to discover her own fire-starting abilities. Enna notices that she can feel the heat given off by all living things, just as the words on the vellum had explained. While trying to keep her abilities a secret, she finds the urge to start fires nearly unavoidable. She finds herself setting flames to help her friend win a duel, which eventually leads to her joining the army's efforts to defeat the invading Tiran.

As news of her fire-starting abilities moves through the land, Enna becomes a target for the Tiran, who seek to use her power for their own advantage-to help them defeat the King's army and Enna's homeland of Bayern. In a rage to save her country, Enna races through enemy territory, setting places ablaze to help defeat the Tiran. And her gift of firestarting becomes more than an unusual ability-it becomes a force of its own that Enna can barely control. The heat builds up within her, and she must find somewhere to send that flame.

Eventually, a leader of the Tiran orchestrates Enna's capture, where Enna is given strong medicine that keeps her firestarting abilities in check. When two of her dear friends from Bayern are captured, she is forced to use her powers for the good of the Tiran. She gradually recognizes that her main captor's own ability to use language to persuade and the medicine are interfering with her own judgment.

Eventually, Enna breaks free from the enemy and joins efforts with her friend, Isi, who is married to the deceased king's son and becomes queen of the land upon the death of her husband's father. She has her own special abilitycommanding birds and the wind. Both find their powers debilitating, to the point that Enna is herself burning to death inside. The two journey to another land, where they hope to find a way to save Enna from the same fate as her brother.

Hale provides an elaborate tale of adventure and bravery, where the heroine seeks a happy-everafter ending on her own terms, knowing that such an ending wasn't possible for her brother and may not be for her, as well. She must decide just how-if at allshe is to use this unusual gift of fire-starting. Enna battles herself, just as much as she takes on the Tiran, as she struggles with remaining loyal to her country and friends while also demonstrating loyalty to her own beliefs.

Hale, Shannon. 2004. Enna Burning. New York: Bloomsbury. 300 pp. ISBN: 1-58234-889-8. US $\$ 17.95$. 